\title{
Study of structural changes in the cells of the stimulated seed sprouts
}

\author{
Stepan Kovalyshyn \\ Lviv National Agrarian University, 80381, Lviv region, Dudliany, V. Velykyy 1, Ukraine \\ Received December 28, 2015; accepted August 22, 2016
}

A b s t r a c t. The paper emphasises that one of the easiest and effective methods of pre-treatment of seed is by industrial electrical power frequency. In order to select the most effective treatment regime it is necessary to reveal the mechanism of the impact of electromagnetic fields on biological structures, including plants. In this regard, electron microscopy studies at the cellular level of seedlings of perennial ryegrass seed treated with electric field corona discharge were conducted. It was found that in seedlings of treated seeds the intracellular organisation of the plant varies, resulting in changes during cell division. This is apparently due to a reduction in interphase, including S-phase, resulting in disrupted normal DNA synthesis, chromatin formation and, consequently, the collection of chromosomes. As a result, the cell division is faster, which leads to increased sowing quality of seeds of studied plants. While maintaining the characteristics of the studied cell division of seedling seed which was subjected to electrical stimulation, there is the prospect of a significant increase of seed germination of ryegrass in the future generations.

$\mathrm{K}$ e y w o r d s: seed, presowing treatment, sprouts, electron microscopy, cell, cell division

\section{INTRODUCTION}

During the implementation of measures for improving seed sowing quality, an important part is that of its preliminary treatment by methods of electrophysical influence: magnetic field, electrostatic field, electric field corona discharge, laser beam, high frequency power, ultraviolet and infrared rays, plasma (Afzal et al., 2012; Bereka et al., 2009; Ćwintal and Dziwulska-Hunek, 2013; Matvijczuk et al., 2012; Pałow et al., 2012).

One of the simplest and most effective methods of pretreatment of seeds is the impact of industrial frequency electric field (Goldman, 2002; Holdaev and Meteleva, 1990;

*Corresponding author e-mail: kovalyshyn@mail.ru
Kovalyshyn, 1999, 2000; Kovalyshyn and Konyk, 2015; Kovalyshyn et al., 2013; Petrovskyy, 2013; Tarushkyn, 2007). Electrotechnological methods of processing and technology using strong electric fields are of little energy intensivity, relatively easily implemented, and environmentally friendly.

Seed stimulation by electrophysical methods produces positive results from 60 to $70 \%$ (Pietruszewski and Kania, 2010; Snitynskyy et al., 2012). For optimal modes, pre-sowing electrotreatment increases seed vigour and germination, plant height, mass of 1000 grains, and an increase of plant productivity in terms of grain yield and nutritional value.

To select the most effective mode of treatment, which is characterised by the electric field, the time of processing (exposure) and softened period (time from start of treatment to the period of germination or planting) should be investigated by the mechanism of action of electromagnetic fields on biological structures, including plants. This question has been and remains the subject of a number of researches, since a common drawback of all existing technologies of presowing seed processing by electric methods is the low frequency processing results. Consequently, it is impossible to determine the necessary parameters of the electric field that would provide a stable positive effect. This can be largely explained by the lack of sufficiently deep theoretical and experimental studies of the mechanism of influence of various physical factors on a seed (Kacheishvili, 2000). 
Therefore, new ways, additional research and development aimed at expanding the study of the mechanism of influence of the electric field on crop seeds are searching for.

By generalization of theoretical and applied researches (Kacheishvili, 2000), it was found that the rate of water absorption appeared to be the main factor that can increase the effectiveness of pre-treatment of seeds. Changes of the electric field intensity in the range of 4.5 to $6 \mathrm{kV} \mathrm{cm}^{-1}$ have a stimulating effect on the rate of seed water absorption. Seeds that absorbed more water in the first 4 hours are more productive.

A number of researchers believe that optimal seed stimulation modes would be the best if set on the basis of determination of biochemical parameters in seedlings of treated seeds (Goldman, 2002), particularly oxide renewable activity of enzymes - ascorbate oxidase, polyphenol oxidase and peroxidase. This was considered the best mode in which the studied parameters in seedlings of treated seeds are higher compared to those in untreated seedlings of seeds.

Other researchers (Rivis and Kovalyshyn, 2000) proposed ways to determine the effectiveness of presowing electrical stimulation of seeds, based on the earlier assessment and selection of substances that are integral membrane and cytoplasmic structures of plant cells - level of esterified and nonesterified high molecular fatty acids - as biochemical indicators. Exploring their content in seedlings, roots and remains of untreated and treated seeds, and their crop quality (vigour and laboratory germination), we can determine the optimum settings for the electrical stimulation.

These studies are consistent with the results obtained in Goldman thesis. They show that when seeds are placed in an electric field the deformation of the membranes of plant cells and the change in their permeability increases the metabolism and energy between the cell and the environment. This can be explained by the fact that the electric field has a significant impact on the state of lipid fatty acids, of which a membrane mainly consists.

The data show that at present the researchers actively study the impact of fields of various nature on biological objects. But among them there is no single theory that describes the influence of electric fields on living organisms, even though the biological effects caused by them are used in agriculture to improve the properties of crop and sowing seeds (Afzal et al., 2012; Goldman et al., 1998; Ksyonz and Kacheishvili, 2000; Kurzin, 2006; Petrovskyy, 2012, 2013; Socorroand Garcia, 2012; Zaginailov, 2006).

The response of seeds to one and the same stimulating factor may be different depending on the variety and quality of seed, processing time and dose, duration of binning and the natural factors and circumstances, etc. For these reasons, and because of the low level of knowledge about the mechanism of action of physical factors and general laws, researches in this area are insufficient. Therefore it is necessary to pass from the accumulation of quantitative data to their rigorous analysis and identification of patterns of electrical stimulation mechanism of pre-impact of structural changes on the cells of seedlings of treated seeds.

\section{METHODS}

For the research seeds of perennial grasses of perennial ryegrass type Drohobych 19 were used. This presowing seed was subjected to electrical stimulation. For this purpose an electric frictional separator which provided or the processing modes was used, the adjustable parameters of which were: the electric field $\mathrm{E}\left(\mathrm{kV} \mathrm{cm}^{-1}\right)$ and duration (exposure) of processing $t(\mathrm{~s})$. The scheme of the experiment: $\mathrm{B}_{1}-$ control (no treatment); $\mathrm{B}_{2}-\mathrm{E}=2.7 \mathrm{kV} \mathrm{cm}{ }^{-1}, \mathrm{t}=3 \mathrm{~s} ; \mathrm{B}_{3}-\mathrm{E}=$ $3.6 \mathrm{kV} \mathrm{cm}^{-1}, \mathrm{t}=3 \mathrm{~s}$.

After the binning time, which was 5 days, the study seeds were set to be germinated. For each treatment we randomly selected samples of 100 seeds in threefold replication. Each sample was placed in a separate Petri dish which was put later in a thermostat for germination at $22^{\circ} \mathrm{C}$.

On the 7th day of germination of seedlings with developed roots and shoots that had occupied the primary leaves and at least half the length of coleoptile, we selected specimens for electron microscopy studies. They were performed to demonstrate the mechanism of influence of pre-treatment on structural changes in the cells of studied seedlings (Goldstein et al., 1984). These studies were performed on transmission electron microscope TEM-100-01 at a voltage of $75 \mathrm{kV}$. This microscope allowed to obtain images of samples of surface captured with high resolution without destroying them.

Preparation of selected seedlings for microscopic study was conducted as follows.

Samples of perennial ryegrass seedlings were fixed in $1.5 \%$ solution of osmium quadrioxide $0.2 \mathrm{M}$ cacodylate buffer $(\mathrm{pH}-7.2)$ in the cold for $2 \mathrm{~h}$. The samples were washed 3 times in the buffer. The obtained fixed samples of seedlings were dehydrated in increasing concentrations of ethanol $(25,50,70,90$ and $96 \%)$, each time for $10 \mathrm{~min}$. Then the material was impregnated in acetone, $2 \times 30 \mathrm{~min}$. Epoxy resin (Fluka) was mixed at the ratio of Epon 812 $4.5 \mathrm{ml}$, DDSA - $2.2 \mathrm{ml}$, MNA - $2.2 \mathrm{ml}$. The material was impregnated in four mixtures of epoxy resin and acetone at the ratios of $1: 3,1: 2,1: 1$ and $2: 1$. The last impregnation lasted $14 \mathrm{~h}$, after which the material was transferred to a polypropylene capsule in the fresh mixture of epoxy resin with a catalyst (5 drops DMP-30 to $10 \mathrm{ml}$ resin), and polimerised in the thermostat consistently at $37^{\circ} \mathrm{C}(12 \mathrm{~h})$ and then at $60^{\circ} \mathrm{C}(48 \mathrm{~h})$.

Sections were prepared on the LKB Ultrotome III ultramicrotome using a glass knife, transferring them on the nickel mesh. Sections were contracted sequentially with $2 \%$ alcohol solution of uranyl acetate and lead citrate. 
Prepared samples were viewed under a TEM-100-01 microscope at a voltage of $75 \mathrm{kV}$, at magnifications of $2200 x$ to $11000 x$.

\section{RESULTS}

As a result of experimental electron microscopic studies we found some changes in the structure of cells of ryegrass seedlings obtained from seeds that were processed in an electric corona field of varying intensity (treatments $\mathrm{B}_{2}$ and $\mathrm{B}_{3}$ ), compared to control samples (treatment $\mathrm{B}_{1}$ ). These changes were studied at different viewing magnifications in the electron microscopy.

Exploring morphology changes in cells of ryegrass seedlings in versions $\mathrm{B}_{2}$ and $\mathrm{B}_{3}$ (magnification of 2.2 thousand times), we made a comparison with control $\mathrm{B}_{1}$ (Fig. 1) and revealed the following. In cells of control samples condensed chromatin is available, and there is a partial spindle formation, indicating that the cells are in anaphase transition of mitosis. In the cells of seedlings from options $\mathrm{B}_{2}$ and $\mathrm{B}_{3}$ we did not see explicit condensed chromatin. This probably indicates that they were still at the interphase stage at the time of electron microscopy. We established that the germination of ryegrass seeds that were subjected to the electrical stimulation increased compared with the control sample. Obviously, the duration of the interphase of studied sprouts cells decreased, resulting in increased cell division rate and, consequently, decreases during germination of ryegrass.

With the magnification of 1: 3000 we revealed some gaps in the cells of seedling seeds from treatments $\mathrm{B}_{2}$ and $\mathrm{B}_{3}$ compared with the control (Fig. 2). With the growth of the electric field the gaps in the cells got larger (Fig. 1b). Over the above impact of the field, the integrity of the cytoplasmic membrane of target cells are partially violated, which probably leads to the violation of their division. Arguably, the damaged cells have disrupted interphase, resulting in condensztion of chromatin being not synchronized with the control. This is evidenced by the existence of different stages in the formation of chromosomes in the treated and control samples investigated in the above conditions (Fig. 2).

Electron microscopy (EM) images obtained at magnification of 1: 6000 (Fig. 3) showed that the effect of electric field intensity $\mathrm{E}=2.7$ and $3.610^{5} \mathrm{~V} \mathrm{~m}^{-1}$ (treatments $\mathrm{B}_{2}$ and $\mathrm{B}_{3}$ ) on the condensation of chromatin in the cells of the seeds and, thus, on the formation of chromosomes, is practically not observed, compared to control. This constitutes a violation of the cell cycle for the given conditions. One manifestation of this effect may be reduced interphase, which results in speeding up the cell division.

Figure 4 shows cells of seedlings of treated seeds of ryegrass under exposure to an electric field with intensity $\mathrm{E}$ $=2.7$ and $3.610^{5} \mathrm{~V} \mathrm{~m}^{-1}$ and cells of control seed, magnification of 7500 times.
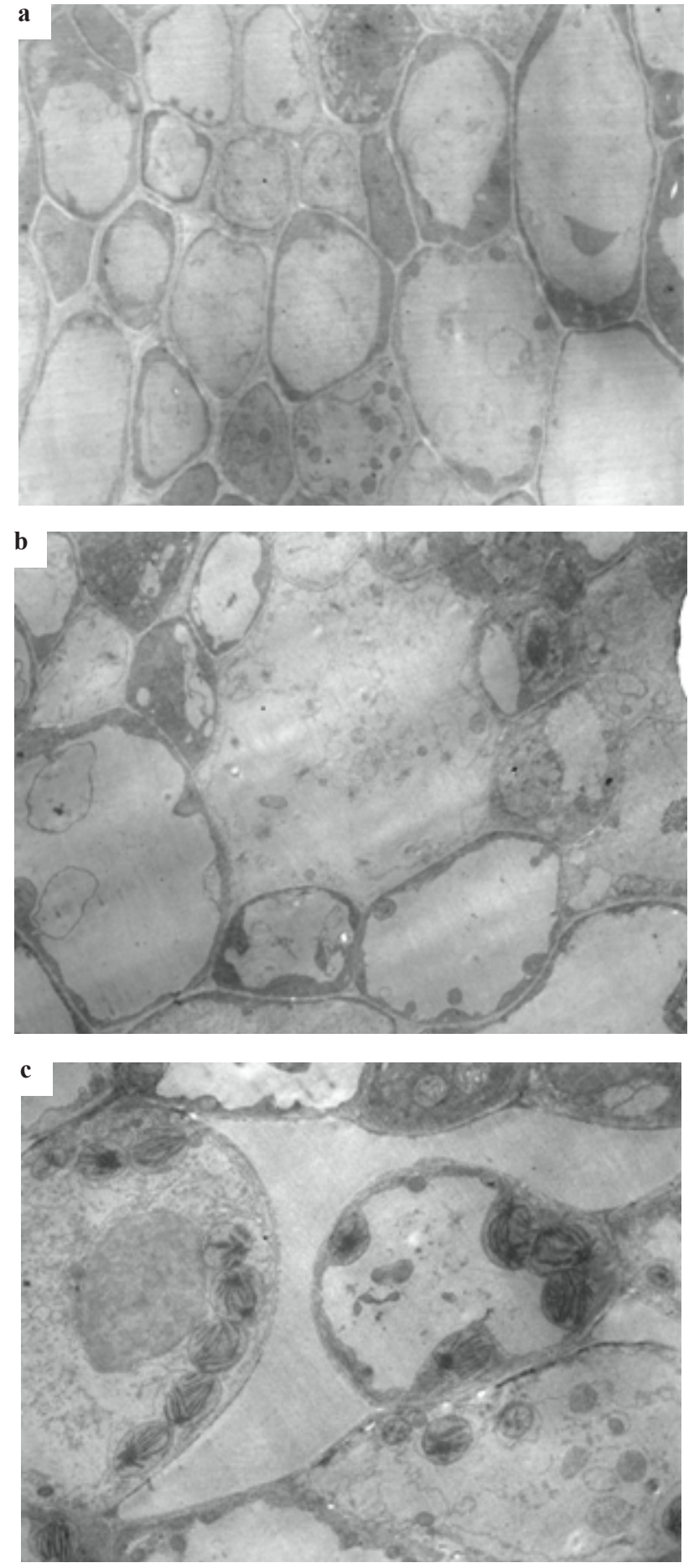

Fig. 1. Electron microscopy image of cells of ryegrass seed at magnification 1: 2200 - seedlings treated in an electric field with intensity of: $\mathrm{a}-\mathrm{E}=2.710^{5} \mathrm{~V} \mathrm{~m}^{-1}, \mathrm{t}=3 \mathrm{~s}$ (treatment $\mathrm{B}_{2}$ ); $\mathrm{b}-\mathrm{E}=3.610^{5} \mathrm{~V} \mathrm{~m}^{-1}, \mathrm{t}=3 \mathrm{~s}$ (treatment $\mathrm{B}_{3}$ ); $\mathrm{c}$ - untreated (treatment $\mathrm{B}_{1}$ control).

Applying the magnification of 7500 times, we identified the presence of gaps in cells of seedling seeds that were exposed to an electric field, compared to the control cells samples. Obviously, this is evidence of violation of the integrity of the cytoplasmic membrane. In the control cells 

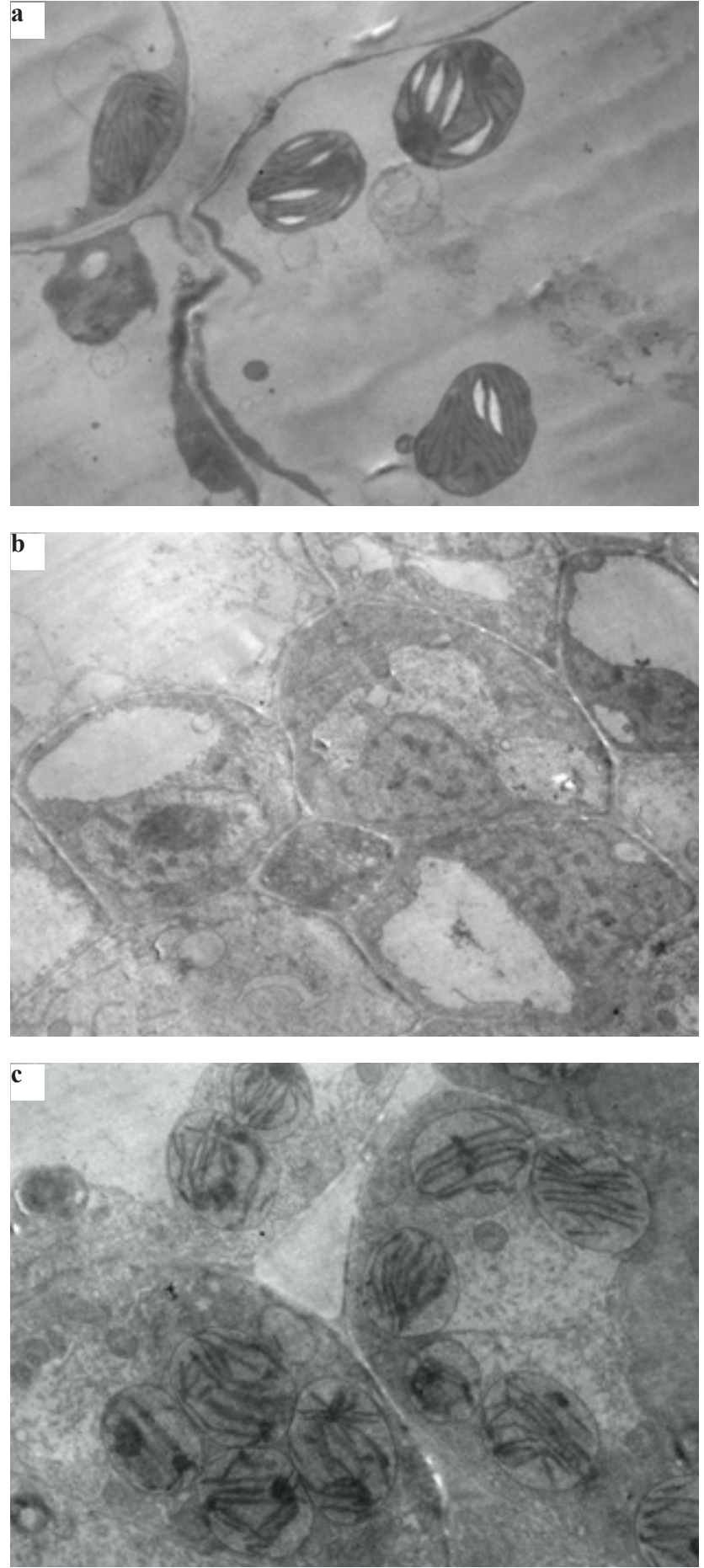

Fig. 2. Electron microscopy image of cells of ryegrass seed at magnification 1: 3000 - seedlings treated in an electric field with intensity of: $\mathrm{a}-\mathrm{E}=2.710^{5} \mathrm{~V} \mathrm{~m}^{-1}, \mathrm{t}=3 \mathrm{~s}$ (treatment $\mathrm{B}_{2}$ ); $\mathrm{b}-\mathrm{E}=3.610^{5} \mathrm{~V} \mathrm{~m}^{-1}, \mathrm{t}=3 \mathrm{~s}$ (treatment $\mathrm{B}_{3}$ ); $\mathrm{c}$ - untreated (treatment $\mathrm{B}_{1}$ control).
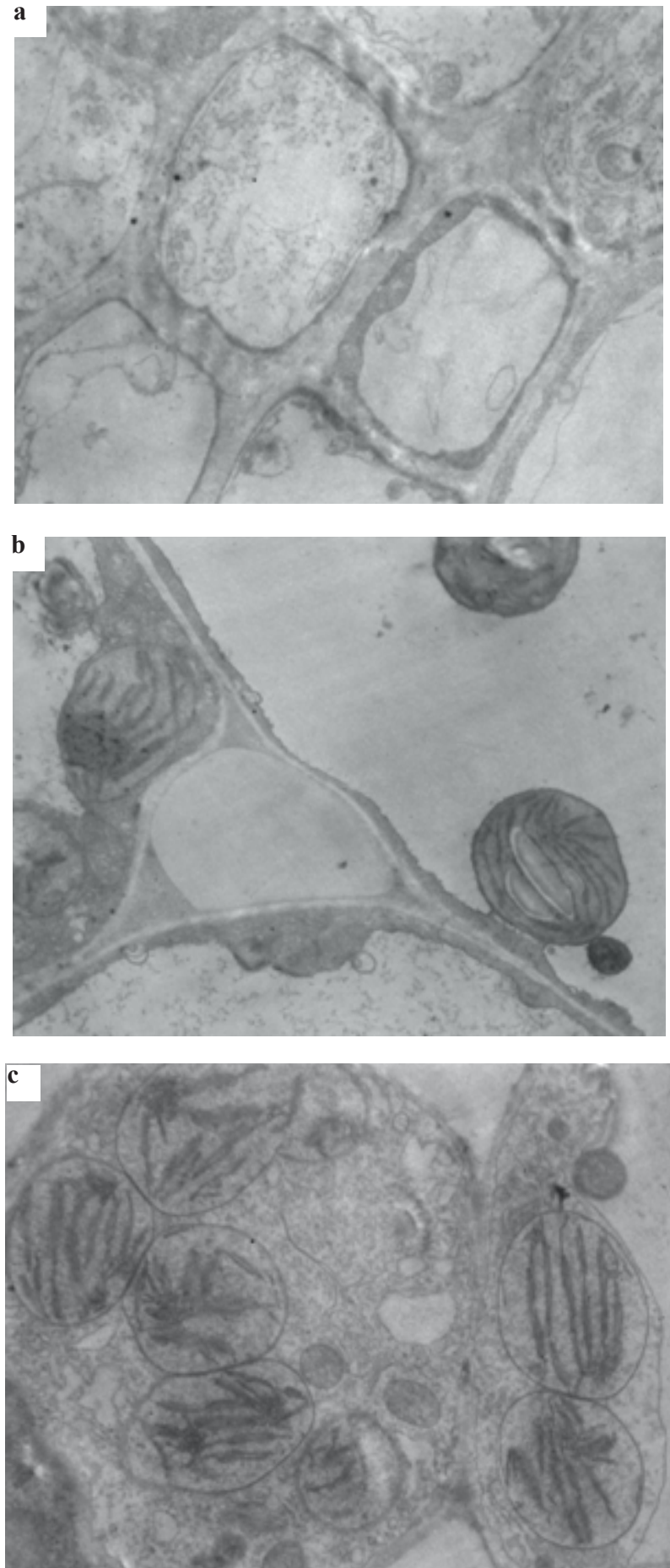

Fig. 3. Electron microscopy image of cells of ryegrass seed at magnification 1: 6000 - seedlings treated in an electric field with intensity of: $\mathrm{a}-\mathrm{E}=2.710^{5} \mathrm{~V} \mathrm{~m}^{-1}, \mathrm{t}=3 \mathrm{~s}$ (treatment $\mathrm{B}_{2}$ ); $\mathrm{b}-\mathrm{E}=3.610^{5} \mathrm{~V} \mathrm{~m}^{-1} ; \mathrm{t}=3 \mathrm{~s}$ (treatment $\mathrm{B}_{3}$ ); $\mathrm{c}$ - untreated (treatment $\mathrm{B}_{1}$ control). 

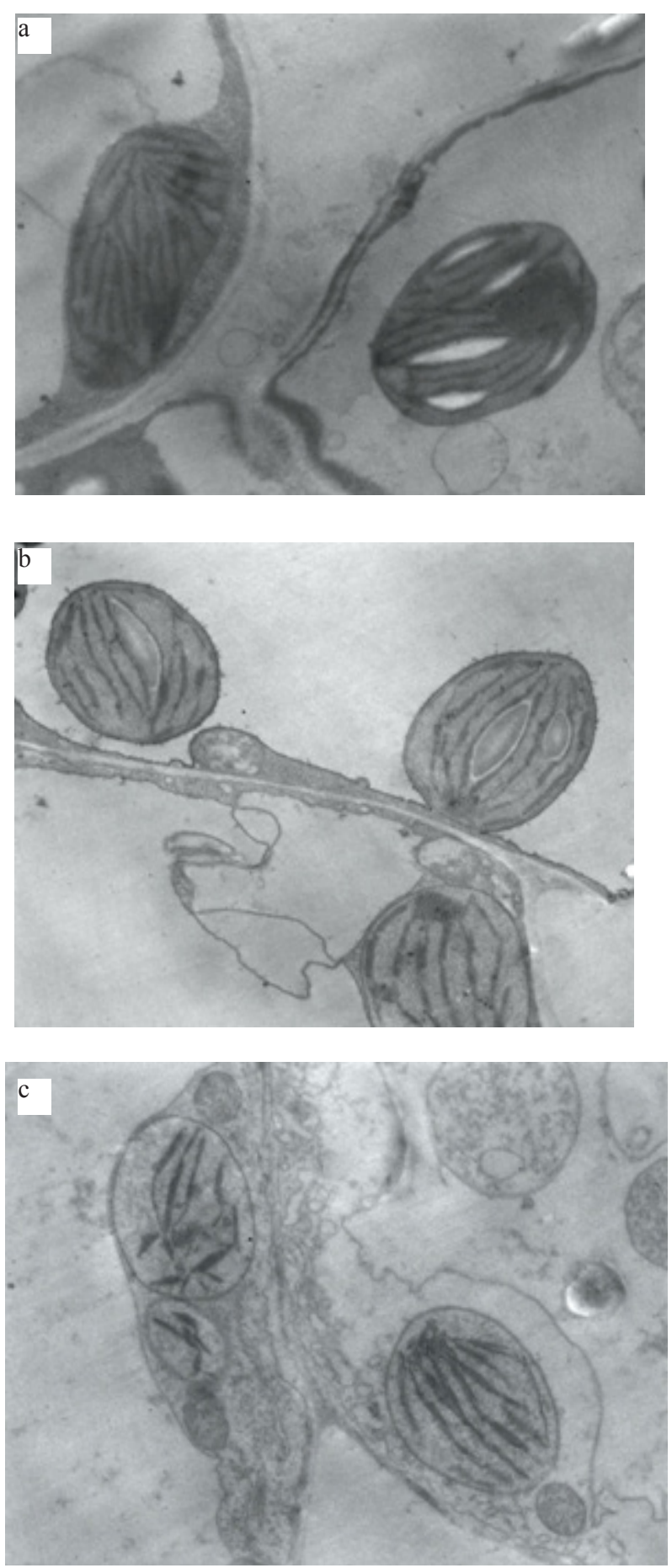

Fig. 4. Electron microscopy image of cells of ryegrass seed at magnification 1: 7500 - seedlings treated in an electric field with intensity of: $\mathrm{a}-\mathrm{E}=2.710^{5} \mathrm{~V} \mathrm{~m}^{-1}, \mathrm{t}=3 \mathrm{~s}$ (treatment $\mathrm{B}_{2}$ ); $\mathrm{b}-\mathrm{E}=3.610^{5} \mathrm{~V} \mathrm{~m}^{-1}, \mathrm{t}=3 \mathrm{~s}$ (treatment $\mathrm{B}_{3}$ ); $\mathrm{c}$ - untreated (treatment $\mathrm{B}_{1}$ control).
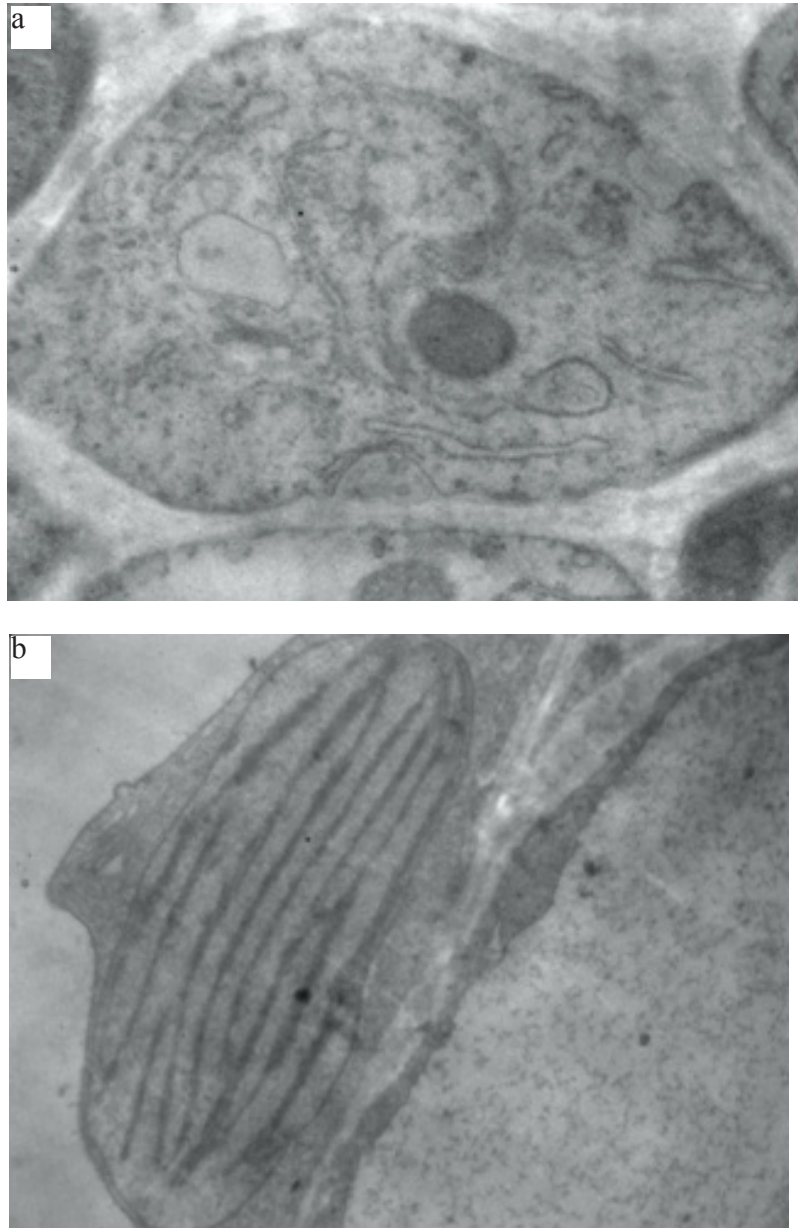

Fig. 5. Electron microscopy image of cells of ryegrass seed at magnification of 1: 11000 seedlings of treated in an electric field with intensity of: $\mathrm{a}-\mathrm{E}=2.710^{5} \mathrm{~V} \mathrm{~m}^{-1}, \mathrm{t}=3 \mathrm{~s}$ (treatment $\mathrm{B}_{2}$ ); $\mathrm{b}$ - untreated (treatment $\mathrm{B}_{1}$ control).

of seedlings seeds we observed an axis of division, and the chromosomes were placed on the poles of cells (Fig. 4b). Perhaps these cells are being in anaphase of the cell cycle. No clear spindle and chaotic placement of chromosomes in the cells of the samples probably indicates their being in interphase and early prophase stage. Thus, cell division in versions $B_{2}$ and $B_{3}$ and $B_{1}$ control version is not synchronized. Because the germination of ryegrass seeds that were subjected to electric field influence increases, the cell cycle is probably accelerated by the above conditions, compared with the control.

Figure 5 shows an EM image of cells of studied ryegrass seedlings at magnification of 1: 11000 . It is shown that by applying a voltage the plants' intracellular organization changes, resulting in the observed changes in the rate of cell division and, accordingly, ryegrass seed germination. Lack of chromatin formation in the treated samples compared to the control indicates the difference between the phases of the cell cycle, which is observed during the determined period. 


\section{CONCLUSIONS}

The conducted studies have proven the effectiveness of presowing ryegrass seed stimulation with an electric field corona discharge.

1. Cells division cycle of ryegrass seed sprouts is violated as a result of the electric field intensity $\mathrm{E}=2.7$ and $3.610^{5} \mathrm{~V} \mathrm{~m}^{-1}$, compared with the control. This is apparently due to a reduction in interphase, including S-phase, resulting in disrupted normal DNA synthesis, chromatin formation and, consequently, collection of chromosomes. As a result, cell division is faster, which leads to increased germination of seeds of studied plants.

2. Presowing electric treatment leads to changes in the integrity of the cytoplasmic membrane of cells of studied seedlings. This may indicate a change in its permeability, a change in the exchange of nutrients and energy.

3. While maintaining the division characteristics of the studied cells of seedling seeds subjected to presowing electric field stimulation, there is the prospect of increasing seed germination of ryegrass in future generations. However, genetic changes of studied cells in different electric field intensity treatments and their impact on the functioning of the cell cycle of studied plants require some further studies.

Conflict of interest: The Author do not declare conflict of interest.

\section{REFERENCES}

Afzal I., Mukhtar K., Qasim M., Basra S., Shahid M., and Haq Z., 2012. Magnetic stimulation of marigold seed. Int. Agrophys.,6, 335-339.

Bereka O. and Usenko S., 2012. Ionization processes in grain weight under strong electric field. Econtechmod: an International Quarterly J. Economics Technology, 1(1), 17-20.

Ćwintal M. and Dziwulska-Hunek A., 2013. Effect of electromagnetic stimulation of alfalfa seeds. Int. Agrophys., 27, 391-401.

Goldman R.B., 2002. The combined effect of low elektromagnetic fields of low and high voltage on rice seeds (in Russian). Ph.D. Thesis, Agrarniy Universitet Kuban, Russian Federation.

Goldman R.B., Kutsenko A.N. Chesnyuk E.E., and Makaseeva I., 1998. The mechanism of action of the electromagnetic field on the solid particles in the liquid medium. Proc. Kuban State Academy, Russia, 370, 98-102.

Goldstein J.I., Newbury D.E., EchlinP., Joy D.C., Fiori C., and Lifshin E., 1984. Scanning electron microscopy and X-ray microanalysis (in Russian). Publisher "Mir" Moscow.

Hadzalo J.M., 2009. Microwave Technology - Step into the future of agrarian industry. Refining Storage Grain, 5, 26-28.

Holdaev V.S. and Meteleva V.A., 1990. Presowing seed processing of perennial grasses by electric field of high voltage (in Russian). Selektsyya Semenovodstvo, 2, 48-50.
Kacheishvili S.V., 2000. Justification processing parameters of cereal seeds in an electrostatic field (in Russian). Ph.D. Thesis, Azov-Black Sea State Agrarian Akademiyayu, Russian Federation.

Kovalyshyn S., 2000. Increase of productive and reproductive properties of seeds of perennial grasses by its presowing electrical stimulatin (in Ukrainian). Coll. Science. Foothill and Mountain Farming, 42, 67-70.

Kovalyshyn S. and Konyk G., 2015. Using of pre-sowing electrostimulation of seed of perennial ryegrass (Lolium perenne L.) for the creation of initial breeding material (in Poland). Acta Agrophysica, 22, 55-65.

Kovalyshyn S., Shvets O., Grundas S., and Tys J., 2013. Use of electro-separation metod for improvement of the utility value of winter rapeseeds. Int. Agrophys., 27, 419-424.

Kovalyshyn S., 1999. Choice of parameters of perennial grass seed processing on an elektro-vibration separator (in Ukrainian). Ph.D. Thesis, Lviv National Agriculture University, Ukraine.

Ksyonz N.V. and Kacheishvili S., 2000. Analysis of magnetic and electric impact on seeds. Mechanization Electrification of Village, 5, 25-29.

Kurzin N., 2006. Impact of electric and magnetic instrumental evaluation of fields on biological objects. Electrification and Mechanization of Agricultural Sector, 11, 11-12.

Matvijezuk A., Kornarzynski K., and Pietruszewski S., 2012. Effect of magnetic field on seed germination and seedling growth of sanflower. Int. Agrophys., 26, 271-278.

Pałow I., Sirakow K., Kuzmanow E., and Armianow H., 2012. Been seeds electromagnetic pre-treatment researches results (in Ukrainian). Machinery in Agriculture, 2, 6-7.

Petrovskyy O.M., 2012. Irradiation method of preplant seed crops with ultrahigh-frequency electromagnetic field. J. Kharkov National Technical University of Agriculture n.a. Petro Vasilenko, 107, 276-283.

Petrovskyy O.M., 2013. Technology of pre-stimulation of seeds with high-frequency electromagnetic field. East Evropeyskyy Peredovyh Technologyy Magazine, 66, 45-50.

Pietruszewski S. and Kania K., 2010. Effect of magnetic field on germination and yield of wheat. Int. Agrophys., 24, 297-302.

Rivis Y.F. and Kovalyshyn S., 2000. Optimum pre-electrical mode parameters (in Ukrainian). Bulletin of Agricultural Science, 6, 28-30.

Snitynskyy V.V., Kovalyshyn S.Y., and Paranyuk V.A., 2012. Scientific prerequisites of controlled electromagnetic effects on the evolution of the productive potential of energy crops genotypes (in Ukrainian). Scientific Bulletin of National University of Life and Environmental Sciences. Series Technology and Energy AIC, 174, 50-58.

Socorro A. and Garcia F., 2012. Simulation of magnetic field on seed embryo cell. Int. Agrophys., 26, 167-173.

Tarushkin V.I, 2007. Dielectric seeds separation (in Russian). Ph.D. Thesis, Sciences, Moscow University of Agriculture, Horyachkina, Russia.

Zaginailov V.I., 2006. Electrical stimulation of bio-tissue of biological objects. Electrification and Mechanization of Agricultural Sector, 1, 25-27. 